\title{
Push It Along: On Not Making an Ethnographic Film in Baltimore
}

Matthew Durington, Samuel Collins , Niajea Randolph , Logan Young

\section{Abstract}

Perhaps the most demonized group following the uprising that occurred after the death of Freddie Gray in Baltimore were the youth of the city. As ethnographers working in the same neighborhoods where the Baltimore Uprising took place, we debated the representations we would make, cognizant that, in an atmosphere of both overt and covert racism, any representation we produced would be subject to political appropriation from the same mass media we were criticizing. However, we were not the only actors in Baltimore's representational field, and, instead of making our own ethnographic films, we began to look to the representations of the city produced by the youth who were directly impacted by the structural forces that precipitated the uprising. In doing so, we are advocating anthropologists on certain occasions to "push it along," or in other words, speak alongside our collaborators to ascertain a more nuanced vision of events through a networked anthropology.

\section{Introduction}

"If you can't pull it, all ya gotta do is push it along, push it along, push it along, yeah, push it along”-Q-Tip from A Tribe Called Quest

The city of Baltimore is tragically overrepresented while fundamentally under recognized. Alongside many 
other so-called minority-majority cities in the United States, it has suffered from post-World War II deindustrialization and the loss of a manufacturing economy while watching a huge segment of its population disappear to the suburbs, exurbs, and Sun Belt. Jobs have gone away, the tax base has eroded, education has become underfunded, services have disappeared when needed most, and a highly racialized perception of the city has been created. As the formal economy dissipated in Baltimore in the throes of neoliberalism in the 20th century, the informal economy that undergirds all capital flows has risen in prominence, as it is one of the few ways in which many have been able to literally survive in Baltimore. One of the many consequences of the informal economy related to illicit drug distribution-now ironically being formalized in many sites within the United States as a legitimate industry — is a rising public health problem. Addiction creates further strains for social services and is one of many factors leading to a rise in forms of criminality linked to substance abuse issues. The concomitant rise in crime from these economic and public health issues creates an over leveraged attention to a population resulting in biased incarceration rates and perceived criminality. ${ }^{1}$ Add one of the highest pollution rates in the country and rampant lead paint poisoning for children living in dilapidated homes in the urban core and one gets a sense of the issues facing children in the city. All of these factors inform a view of the city as a dangerous space and become the fodder for a "representational burden" of Baltimore in popular culture as seen in shows such as Homicide, The Corner, and The Wire. ${ }^{2}$ The mediascape created during the Baltimore Uprising of 2015 following the death of Freddie Gray now compounds the perception and the predicament of Baltimore City already in place.

As noted in an incredibly comprehensive set of resources provided by the Baltimore Sun, Freddie Gray, aged 25, was arrested on the morning of April 12, 2015. ${ }^{3}$ According to the police, Mr. Gray made eye contact with police at approximately 8:39 a.m. and fled unprovoked. Between 8:40 and 8:46 a.m., Freddie Gray was apprehended by police and violently placed in a police transport van. Video footage of this incident became part of the national mediascape when the police version of the incident was countered by video taken at the scene by community members showing Mr. Gray in pain, being dragged by his feet into the van. A number of stops were made to pick up other individuals before the police transport vehicle arrived at the Western District Station of the Baltimore Police at 9:24 a.m., when paramedics were called to transport Freddie Gray to the hospital. In later accounts of the journey between his arrest and arrival at the police station, the practice of giving arrestees in police custody a "rough ride” was leveled at individuals in charge of Mr. Gray. A "rough ride" is when an individual is not secured in the vehicle and their body is tossed around within the vehicle as they are being transported. In the following days, Mr. Gray underwent surgery and fell into a coma.

On April 18, the first protest over the arrest and injury of Freddie Gray was held at the Western District Station. On the morning of April 19, Freddie Gray died. In the following days, six officers were suspended from the Baltimore Police but denied using excessive force. Protests continued to grow as the Justice Department of the United States launched a federal investigation on April 21. Governor Larry Hogan deployed Maryland State Police to the city of Baltimore. On April 25, a protest of over 1,000 people commenced at Baltimore City Hall, and twelve people were arrested for a variety of incidents including reports of damage to police cars and a convenience store. On April 27, Freddie Gray's funeral was held, and that night a large series of incidents occurred throughout the city. A curfew was set the next day by the mayor of Baltimore and more incidents occurred as protests spread to other cities. 
For those of us who have been working and studying socioeconomic issues and race in Baltimore, the uprising that occurred in April 2015 did not come as a surprise. Rather, it was the result of years of disenfranchisement coupled with processes of deindustrialization that left the Baltimore's urban population in some of the most problematic socioeconomic conditions in the United States in the 21st century. As witnessed on screens throughout the world, one of the most documented and demonized groups during the uprising following the death of Freddie Gray were the youth of Baltimore City. As ethnographers working in the same neighborhoods where the Baltimore Uprising took place, we debated the representations we would make, cognizant that, in an atmosphere of both overt and covert racism, any representation we produced would be subject to political appropriation by the same mass media we were criticizing. As visual anthropologists, our initial instinct was to create an ethnographic film or some other form of anthropologically intended media as we had done in our project Anthropology by The Wire. However, we were not the only actors in Baltimore's representational field, and, instead of making our own ethnographic films, we began to look to the representations of the city produced by the youth who were directly impacted by the structural forces that precipitated the uprising.

As events unfolded in Baltimore, the youth producers of Wide Angle Youth Media, a local nonprofit, were heralded in newspapers as part of the peacemakers helping quell protests and bringing calm to the city. Our co-authors, Niajea Randolph and Logan Young, both high school students in Baltimore and part of Wide Angle Youth Media, were just two individuals that both embodied and created alternative representations of Baltimore youth that predominant media often ignored. We felt it was time to let their voices be heard, as well as our own.

What does it mean to be a media anthropologist in Baltimore in the year 2016, nearly a year after the Baltimore Uprising in a city that still waits for justice on multiple levels? We asked ourselves this question as the events started to unfold in Baltimore following the death of Freddie Gray. While navigating the mediascape and the city during the uprising, we became part of conversations and teaching moments in communities, in our classes and among our friends. Even basic descriptors themselves were politically loaded. If folks discussed the events as a "riot," then they were already buying into a negative perception of the city; over the days and weeks that followed, that perception would be repeated and compounded by a corporate media machine. If someone mentioned the "unrest," then there was at least an attempt to find some nuance in the situation. But, the use of the term "uprising" signaled a critical approach that recognized larger structural conditions that surrounded the events in the city and also signaled a possible attempt to look for alternative media that provided a different perspective from what was being nationally produced about Baltimore. It also foregrounded a wider discussion of the "right to the city" (Harvey 2013) and who actually had the right to protest in Baltimore. One important source of alternative representations came from social media that provided a perspective from the ground up. If one referenced the attempts of community organizers on Twitter, shared the pictures from local peace marches on Instagram or Facebook, or followed the efforts of Wide Angle Youth Media on diverse social media platforms, it facilitated an alternative perception. This alternative perception relied upon the social reality on the street rather than on the stereotypical representations of Baltimore by national media making yet another round of aberrant portrayals, 


\section{The Wire is Still With Us}

In 2010, we (Collins and Durington) became increasingly frustrated as the infamous television series The Wire became the primary media representation of the city of Baltimore. While the show presented a somewhat realistic and neorealist depiction of the city that relied upon certain documentary practices and an unfortunate alignment with actual news stories of violence and corruption, it did not necessarily represent the Baltimore that those of us who live and work here know. It certainly did not represent the residents with which we interacted on a daily basis or worked collaboratively when dealing with issues ranging from gentrification to student volunteerism. Yet, due to its popularity and coverage in the media we knew that "Baltimore" forged a strong association between violence, crime and the city in the national and international imagination. We decided to apply for funding from the National Science Foundation for a research experience for undergraduates grant in 2010 and received funding for four years from 2011 to 2015. The project, Anthropology by The Wire, was intended to bring undergraduates into an immersive media and methodology training seminar and place them in collaborative media partnerships with Baltimore residents. The goal was to create a series of participatory media projects that would create a mediascape that did not necessarily contest the representations of Baltimore in The Wire, but would stand alongside the series as a different set of depictions of "Charm City." The project was very successful over the 4-year run with a number of different media outcomes that can be found on the archive site of the project (anthropologybythewire.com). The work continues in different forms today and informs curriculum and practice. Yet, the specter of The Wire continues to be the lens through which many view the city of Baltimore and this was quite apparent during the uprising.

As Logan, a youth producer with Wide Angle Youth Media, attests, if the national media had turned the lens a different way they might have seen something different in Baltimore during the uprising. Unfortunately, the perception of Baltimore City is guided by a set of stereotypes about urban residents that emanate from a variety of media but most problematically through a reliance on The Wire. Although only a child when the show originally aired, he feels as if the show still impacts his life:

Nationally it is The Wire, The Wire, The Wire...we are just like any other city where Blackon- Black violence is rampant, drugs are rampant...police are being bullies in the community. There is poverty. It's all true. None of it is made up. They look at all of us the same... the media portrays only violence but there is another Baltimore that they could show like some of my peers in high school... the kids that have the privilege to go to a great high school like me and take advantage of it. They don't want to focus on my peers that are going to Yale or to Harvard who come from the same streets and communities... they don't want to focus on that. The media only portrays the negative, but what I do is the positive. My school is the positive.

Wide Angle is the positive. There are so many positives that could outweigh the negatives if they portrayed that. A lot of times the negatives get more viewers... it's what people want to hear and 
The attempt to show a positive view of Baltimore does not necessitate a kind of fictionalized ethnography or dramatization; Baltimore residents do not need a sunshine-and-butterflies version of The Wire, The Corner, or Homicide. As we have learned through our project Anthropology by The Wire and our research in a Networked Anthropology, the positive representations produced by citizens of the city far outweigh the negative portrayals that exist. This fact is not just our bias or love for Charm City. Some of these positive representations are community gatherings, block parties, daring motorcycle exploits and videos of the unique type of marching band that only Baltimore creates from its city blocks and churches. These positive images of Baltimore run counter to the sobering statistics and other social facts about growing up in the city, particularly in the 21218 zip code that was the epicenter of the uprising and the impromptu national media headquarters for days thereafter. ${ }^{4}$ But these indicators, such as employment and income, are not about the people themselves, they are about the larger processes of deindustrialization, urban renewal, and lack of resources that urban residents face. The saving grace of The Wire for us is in the attention David Simon gave to those larger structural forces. However, Simon's indictment of structural inequality was not what most national and global audiences took away from the series about Baltimore. Instead, The Wire's audience saw their stereotypes confirmed in a Baltimore represented as violent, drug-ridden, and dysfunctional.

Nevertheless, and despite numerous critiques from different Baltimore activists and others, academics (and anthropologists) continue to utilize HBO's The Wire in their classes. Yes - the series (and other David Simon productions) highlights structural racism in a way that mass media almost never does, but, in the end, The Wire is another police drama, one that bounces between realizations of racial inequalities and pathologizations of the urban poor. Sociologist William Julius Wilson, who taught a course on the series at Harvard University, affirms in an interview, “Although The Wire is fiction, not a documentary, its depiction of the systemic urban inequality that constrains the lives of the urban poor is more poignant and compelling than that of any published study, including my own." 5 In the years following the end of the series, an increasing number of course syllabi, from sociology and anthropology, had begun to focus on The Wire, rolling it out to their classes not as a media text, but as an ethnographic portrait of African American Baltimore. Indeed, for many university faculty, the line between media fiction and ethnographic fact proved very gray indeed. Wilson continued, "What I'm concentrating on is how this series so brilliantly illustrates theories and processes that social scientists have been writing about for years.” For others, a little more cognizant, perhaps, of the difference between ethnography and fiction, The Wire became a lesser of evils-a way of soft-pedaling a critique of structural racism to white students. As Anne-Maries Makhulu discussed in 2010 of her inclusion of the show in her anthropology course, “There's this question of how you appeal to young people who feel—not all of them but many of them-far removed from the type of people who are the major characters in The Wire."6

Fast forward to 2015 and the Baltimore Uprising and revelations of systematic police brutality. What about The Wire then? Disturbingly, mass media deployed images from the series to explain protests. Even David Simon was critical; as he told an interviewer in August of 2015: 
There is a lot that a drama can do, and it certainly has a role. But right now it struck me as being inappropriate, that with all the actual substance of what is happening in the streets right now, in the halls of power right now, we need to be straining this through a drama. Why are you doing this? What was it that made people at various publications and blogs reference The Wire just because it was Black people in Baltimore?. ... Why don't you attend to what's actually happening right now in Baltimore? You don't need McNulty or whoever to access it. ${ }^{7}$

The uprising prompted many to reconsider the salience of The Wire for understanding. Dave Zirin, cultural critic and sports writer for The Nation, wrote,

This is humbling to admit, but this experience has made me reassess my favorite show, as if a very dim light bulb was being switched on above my head. I am now seeing what the The Wire was missing, despite its much lauded, painstaking verisimilitude: the voices of people organizing together for change. Everyone on The Wire seeks individual solutions for social problems: the lone cop, the lone criminal, the lone teacher, the lone newspaper reporter. Yes, it is certainly true that when entrenched bureaucracies battle individuals, individuals lose. But when bureaucracies battle social movements, the results can be quite different. ${ }^{8}$

Zirin's confession addresses the somewhat obvious shortcomings of utilizing a police fiction as a synecdoche for a real city, but it also suggests deeper problems. We would submit that The Wire is realistic, not for its “ethnographic portrait” of Baltimore, but for its representations of White understandings of Baltimore, of race, and public policy. But this hasn't been the way it's been embedded in course syllabi.

In the months since the uprising, though, we still see numerous anthropology classes with The Wire in their syllabus. Why? And why not the slew of alternative media produced by groups such as Wide Angle Youth Media? Perhaps there's a certain intellectual laziness there, but we also want to suggest that this reliance on The Wire to tell the problem of racism in the city points to the failures of anthropology to come to terms with social media and, through it, the democratization of ethnographic representation. Anthropologists have long looked to indigenous media as one way of interrogating hegemonic representations, but we suggest another possibility: social media. While the prospect of “master" narratives for Baltimore's problems may be attractive to mass media, people in Baltimore generate multiple media in their everyday lives that they post and share on YouTube, Facebook, and Twitter. The problem with anthropology is our obdurate refusal to take these media seriously and partner with interlocutors in their production. If anthropologists had looked to social media they would have found many counter narratives to dominant media portrayals of Baltimore and a more nuanced contextualization of what was happening.

Perhaps one of the most striking moments of counter narratives being produced and recognized during the 
uprising occurred when local activist Kwame Rose confronted legendary and sensationalist reporter Geraldo Rivera while he was producing the typical "on the street” report. A visibly uncomfortable Rivera ironically evaded Rose behind a Black bodyguard as he was asked about why he will not talk with him about the real issues at hand. Rose began to list a set of critical issues in Baltimore City from housing issues to homelessness while asking Fox News to leave Baltimore because they were not recognizing the larger structural conditions that face the city. In this moment, Rivera became the proxy for the larger broadcast media who were in Baltimore only to cover the potential for violence rather than the structural violence that has been committed against the urban population for decades. Rose damningly stated, "You are not here for the death of Freddie Gray, you are here for your story.” In a surprising and somewhat respectful moment, the broadcast media relent and the camera goes down as Rose pleads for a critical conversation with Rivera without the cameras on stating, "I want the white media out of Baltimore City until you report the real story." The video clip of Rose's encounter made its rounds through Baltimore communities via YouTube and other social media. Ironically, all the media needed to do was look at a group of teenagers and what they were documenting: the solution to Rose's challenge was right in front of them (Figure 1).

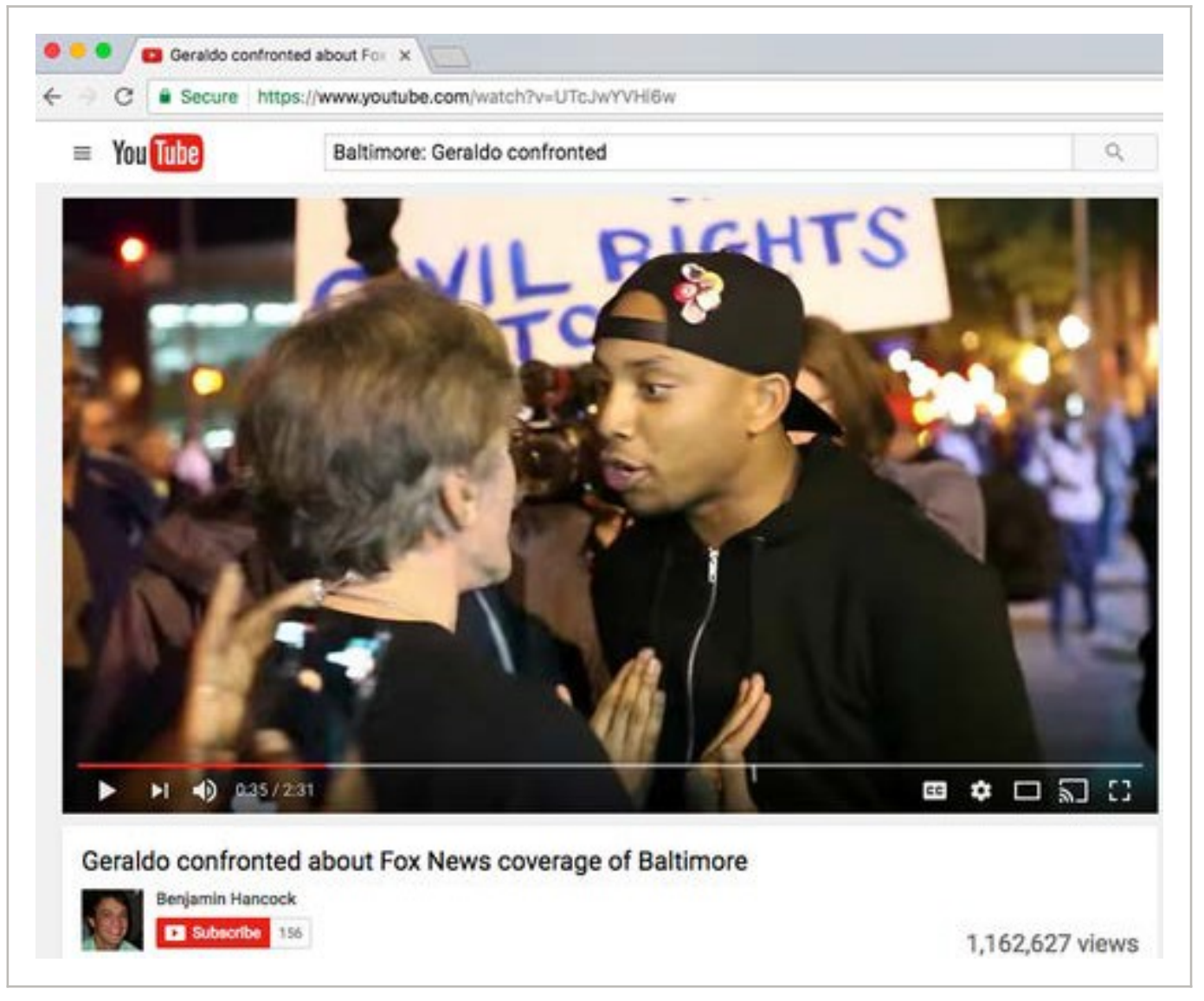

\section{Figure 1}

Screenshot of YouTube Video "Geraldo confronted about Fox News coverage of Baltimore" (https://www.youtube.com/watch?v=UTcJwYVHi6w). [Color figure can be viewed at wileyonlinelibrary.com] 


\section{Wide Angle Youth Media}

Wide Angle Youth Media is a nonprofit organization in Baltimore focused on providing Baltimore youth with media arts training to facilitate a means for youth to tell their own stories. They have a comprehensive teaching program that covers all aspects of media production and several outreach programs and events. They have served over 3,750 Baltimore City youth through their programming and have been recognized as one of the best nonprofit organizations in the city of Baltimore. Over the years, they have produced over 150 videos on a variety of topics from school truancy to homelessness with one of their videos recently admitted to the Tribeca Film Festival. We have witnessed the power and agency of this organization first hand through our project Anthropology by The Wire where we put Wide Angle youth producers in the role of media instructors for our college students. As advocates of this organization we have also served as “carriers” for their social media presence and have assisted in a number of efforts to help the organization.

When the Baltimore Uprising occurred, many of the Wide Angle students were lauded for their efforts in local newspapers as peacemakers as they began to document the events unfolding and offering their voices. Out of all the mass media-produced discourses that emerged during the uprising, it was the demonization of youth that was most troubling. At the outset the City of Baltimore responded to a potential social media threat of a so-called "purge" and essentially fashioned all of the elements for a potential riot when they shut down public transportation on the afternoon of April 27 and abandoned huge swaths of students as they were getting out of school. ${ }^{9}$ This led to the imposition of a curfew by the mayor of Baltimore and the first time she used the coded word "thug" to describe youth in the city. 10

Our co-author Niajea Randolph, a Wide Angle Youth Media producer, was one of those students riding a city bus watching the events unfold around her and made her experiences that day the focal point of the video she produced for Wide Angle (Figure 2): 


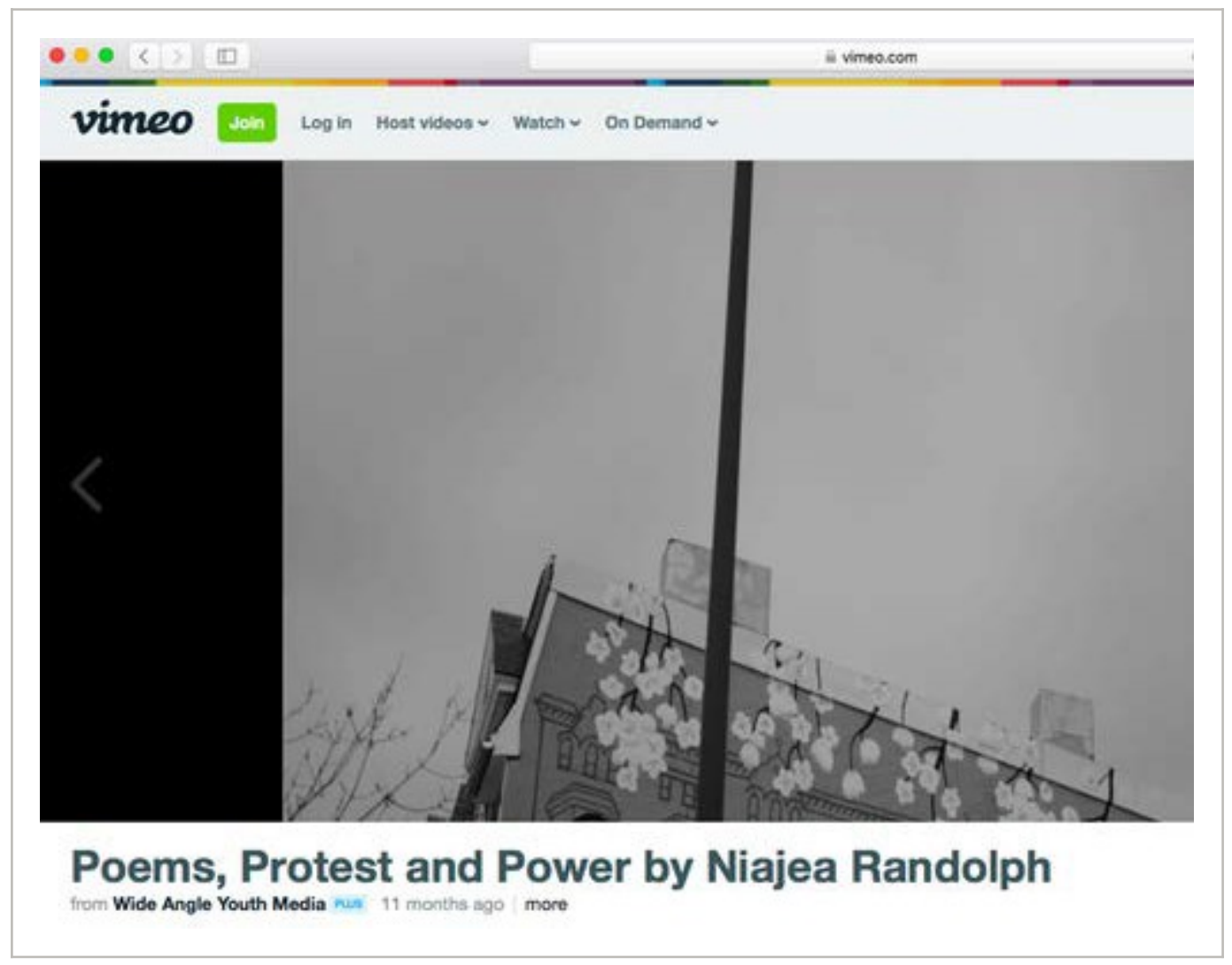

\section{Figure 2}

Screenshot of "Poems, Protest and Power by Niajea Randolph," Wide Angle Youth Media (https://vimeo.com/155700950). [Color figure can be viewed at wileyonlinelibrary.com]

I was just leaving a poetry slam and ended up on a bus downtown with the protest right behind me. In the video, I started off with a part of my poem (that was about how angry I was with the police) and then it goes on to exactly how I went downtown to go to my bus stop and I kept hearing people say that "they" are coming. I finally knew whoever "they" were because I saw things on my phone about the Freddie Gray protest happening up the street. That was exactly when my bus came, so I got on it and I was debating on whether I should get off and join the protest and go home but I had to go home.

Niajea decided to go home that day but the coverage of the uprising she viewed on national news media informed her decision to make a video about her own experience and her sentiments about the way Baltimore and its youth population were being represented: 
I watched a lot of live media coverage. I mostly watched live streams of protesters on Ustream and other live streaming apps. I tried not to watch CNN but I did just to see what they were talking about. As I watched CNN and other channels, they made Baltimore seem like a city full of nothing but careless hooligans. They were saying any and everything about Freddie and the protests to attempt to justify Freddie's death because of the city's reaction.

There are two important aspects from Niajea's comments. One, her own viewing practices using a mobile app service called Ustream is direct evidence of the utilization of smartphones and apps by youth. Second, she was able to see very clearly that the national media was portraying Baltimore in a stereotypic and sensationalist fashion that did not represent her view of the city and its youth:

... the Baltimore that they saw on the news was angry and the violence that followed shouldn't be the only thing that's being talked about. An innocent Black man was killed. The protests didn't happen "just because.” We're tired. We're tired of seeing, hearing even thinking about innocent Black people being killed, and it's not just that! People forget that all of the madness didn't just happen because Freddie was Black, innocent, and killed for no reason. People forget that all that anger was because the officers that were involved with Freddie might be walking away as innocent men/women. So, after years and years of peacefully protesting the abuse and discrimination of Black people, it was the people's breaking point.

Niajea's colleague, Logan Young, produced a similar video entitled “Inaugural”

(https://vimeo.com/155484434) in the aftermath of the uprising that evidences a growing political sensibility.

As his video details, he decided to create a list of demands for the Baltimore City Public Schools, housing issues and the criminal justice system, and called for a sit-in at the Baltimore City Hall. In our conversations with Logan, he was able to describe much like Niajea that the uprising was not just about one instance but a growing sentiment of injustice:

The death of Freddie Gray was not the only reason for what happened. There were factors that led up to it like a lack of education, psychological factors, spiritual factors, nutritional factors... all those things that work in the mind of a person who says, "Hey, I'm going to break somebody's window.” What I like to say to people who say it was just a riot or that they were belligerent or that they are thugs... my question to other Black people is how are you different and they usually say because I was raised better and then I ask, “Why did your parents raise you better?” You keep going until you get to the core of it where you were privileged because you had a better education or better parental support, you had more money, you did not have to resort to being in 
the street... you didn't have to resort to violence in any part of your life and you may not have even been surrounded by violence or poverty so you did not succumb to it. My brothers and sisters in the community are surrounded by violence, surrounded by poverty... what do you think is going to happen when they get a moment to say: "Hey, all this anger that I have built up over my life, seeing White people in the Inner Harbor, strolling down the street like there are no problems in the city. [These Whites don't] recognize that my brothers and sisters are dying every day in the streets. [A]nd now I have a national stage to show that I am angry.” That is really what happened. It was not the "thugs", it was not the looters, it was anger from neglect and from so many other factors. It was the food deserts. In Sandtown/Winchester what do you think is going to happen when someone does not have proper nutrition for their child?” (Figure 3)

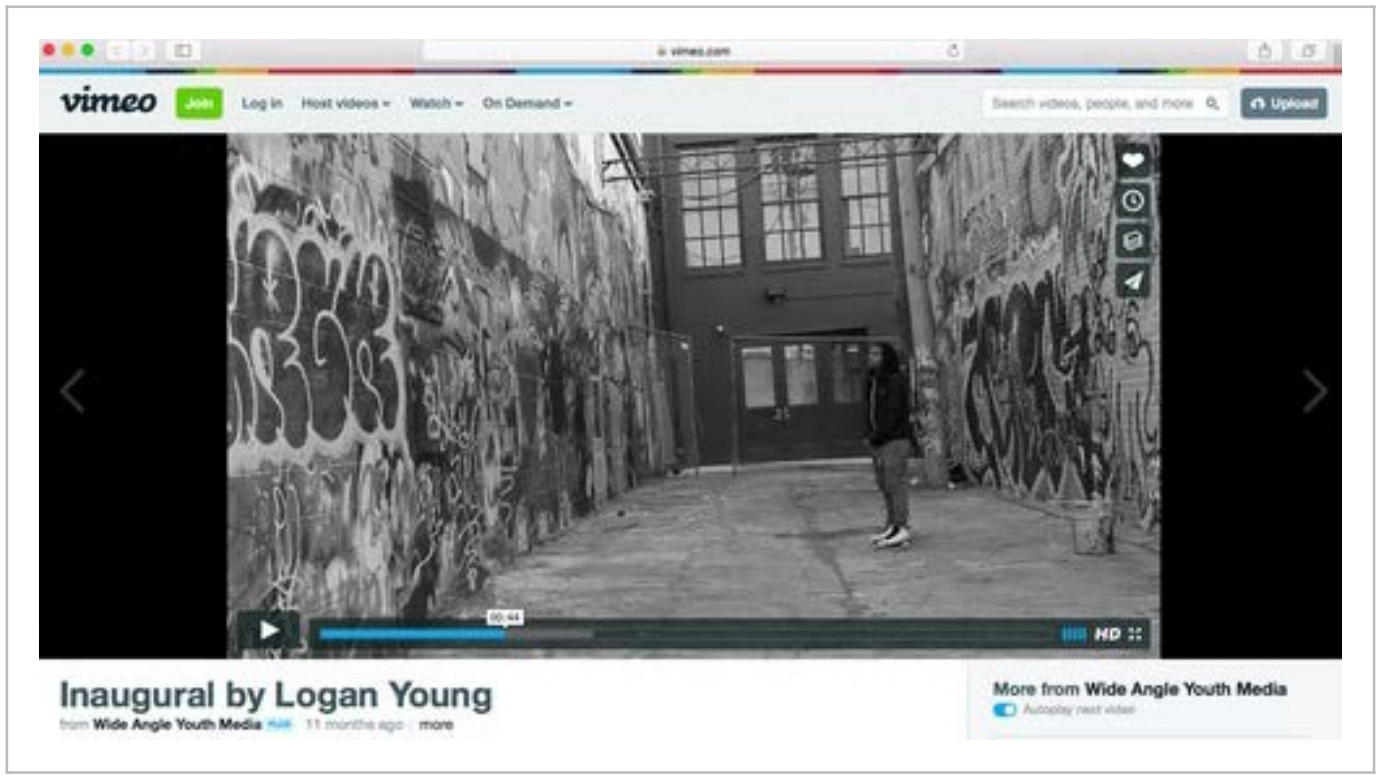

\section{Figure 3}

Screenshot of "Inaugural by Logan Young", Wide Angle Youth Media

(https://vimeo.com/155484434). [Color figure can be viewed at wileyonlinelibrary.com]

Unfortunately, the ability to link the uprising to a larger socioeconomic context did not exist in the national media coverage commented on by our co-authors. As we stated in the beginning of this article, those of us who have been working and studying Baltimore were not surprised when the uprising occurred in April of 2015. It also did not come as a surprise to the youth producers of Wide Angle Youth Media, who had been documenting many of the issues that informed the protests leading up to the uprising that occurred. The two videos by Niajea and Logan are just two reflections on the Baltimore Uprising out of many produced by Wide Angle. In the months since the uprising, Wide Angle Youth Media has created a strong archive of various 
media projects that address the event (https://vimeo.com/wideanglemedia/videos

). As "carriers" of their

media, can we serve as ethnographic conduits to our academic community and facilitate the use of this mediascape, rather than reinforce problematic representations of Baltimore that we have noted?

\section{What, If Not Ethnographic?}

There are no shortages of professional and paraprofessional representations of Baltimore. These documentary and ethnographically intended representations are a micro-second away on any Google search, there for anyone to find. But there is something else as well. In the 1990s, many of us in anthropology and elsewhere researching the information society critiqued a digital divide that disadvantaged multiple groups of people, including people from Baltimore without access to computers and the tools of digital production. However, in the intervening decades, many things have changed that have challenged some of our facile assumptions about digital divides. The Pew Research Center, in their analysis of how different demographic groups utilize media, has documented the growth of social media across the United States-their surveys suggest a more complex picture of digital media and inequality, especially with regard to people living in cities. ${ }^{11}$ Of course, one might look to what has been called the "second-level" digital divide, not premised on the access to digital media, but on the knowledge to effectively take advantage of digital platforms. ${ }^{12}$ Here too, the Pew data suggests a different picture. Indeed, there is a deep and wide social media presence of people in Sandtown where Freddie Gray lived and elsewhere in Baltimore. What about these representations? If not ethnographic, they nevertheless suggest an ethnographic dimension and even an auto-ethnographic sensibility.

We are not advocating some ethnographic version of "data scraping," where we pillage social media to draw a composite portrait of Baltimore City from its residents. There are many things wrong with this approach. To begin with, this is not the intention of many people posting media before or after the uprising. People who post media on social networking sites have the expectation of what Alice Marwick and danah boyd call "Networked privacy... an ability to control their situation, including their environment, how they are perceived, and the information that they share” (Marwick and boyd 2014:1056). So, appropriating these media is certainly ethically problematic. But data scraping would also be methodologically and theoretically suspect. The problem is not just that we do not take these media seriously and regard them as genuinely anthropological but that we don't take them seriously as networked media. When anthropology has occasionally paid attention to social media, it's been media such as film, photos, and audio that just happen to be on SNS (Social Networking System) platforms. But this ignores the network - the sharing and connectivity that are inextricably linked to the content of these media.

The consumption, and, ultimately, the meaning of these media is embedded in a network of people (or accounts) that are constitutive of the meaning of these media. Without these "likes," without shares, re-posts, re-tweets, and comments, there are no social media. As ethical anthropologists, the only possibility for us is to engage these media socially. In general, the failure of anthropology here is at least twofold: the failure to consider social media, and the failure to engage social media in the networked ways in which they were intended. But what would that mean? In Interpretation of Cultures, Clifford Geertz gives us a problematic definition of ethnography as "like trying to read (in the sense of 'construct a reading of') a manuscriptforeign, faded, full of ellipses, incoherencies, suspicious emendations, and tendentious commentaries, but 
written not in conventionalized graphs of sound but in transient examples of shaped behavior” (1973:10).

There have been at least 40 years of critiques against the power inequalities implicit in Geertz's definitionthe othering gaze of his ethnography, the epistemological privilege of the ethnographer. Less questioned, though is the assumption in Geertz about what constitutes a good story. He assumes that it involves the creation of a manuscript: writing a good story. After all, isn't this what makes Geertz's “Deep Play” such an enduring text? Ultimately, public anthropology, or, at least, some versions of public anthropology, echo Geertz in the desire to reach an audience and build a public through the strength of strong narratives. It tells a story and anthropologists have always been storytellers, even when they insist that their stories are empirically true.

But what happens when there are already stories? These can be progressive narratives and progressive media. Or, these can be reactionary, racist narratives like the ones we saw play out on national media about the Baltimore Uprising. Indeed, Baltimore has plenty of both of these. But they are media that ignore, or even systematically elide the self-referential and ethnographic work of people living in communities on social media. An older narrative would seek to build more "postmodern” texts premised on the "ellipses, incoherencies, suspicious emendations, and tendentious commentaries” that Geertz (1973:10) is trying to (literally) read over, but we are not suggesting this either. Instead, engaging social media as social media means working within social media: connecting, liking, re-posting without trying to dominate through narrative synthesis and authoritative account as anthropologists often do.

We can call this an ethic of bad storytelling-refusing to follow Aristotelean drama and structure experience into a beginning, middle and end. For residents of Baltimore, it means not letting a mass media narrative, or an anthropological one for that matter, represent place over the heads of people's own ideas of their lives, even if those representations are progressive and well meaning. It also means taking people seriously as knowledgeable, as capable of their own media representations, and as colleagues who, to be honest, do not need anthropologists to carry out their lives or representations of their resistance during an uprising.

\section{Anthropological Slacktivism}

Wide Angle Youth Media now has a book out called

This Is Baltimore. Baltimore resident and teenager Destiny Watford is a co-founder of "Free Your Voice" and has just won a major victory for environmental justice by helping to shut down what would have been the largest trash incinerator in the United States. Her activism earned her the prestigious Goldman Environmental prize for $2016 .{ }^{13}$ United Workers are looking for new staff. The local National Public Radio station has posted an incredible collection of photos from the Baltimore Uprising in a massive archiving effort. Our responses as anthropologists? Depending on the social media platform: “Like”; "Retweet”; “Share”; “Follow.” Perhaps those are not even "responses”. We haven't done anything — we haven't even moved from our offices! Even J.G Frazer had to get up to pick up another tome of hermetic folklore. But we would be remiss not to engage in this slacktivism. Not only remiss, we would be endangering our relationships with our Baltimore interlocutors. Public anthropology takes many forms - including advocate, gadfly and cultural critic. But what about carriers? The image of "carrier” conjures up people struggling to haul other people's luggage, but here we mean something more like “carrier 
wave”- sending a signal to amplify another.

The digital, networked world in which we live has enabled unparalleled access to the tools of content creation. But for every would-be filmmaker who uploads their work on YouTube, there needs to be agents that propagate media through a network. This is the moral dilemma of slacktivism: despite the tepid support a "like” or a "share" represents, political action undertaken through digital networks require agents to "route" messages through their own networks, and to do so while limiting their own commentary or added content. In other words, digital creators need armies of people to pass along messages to all of their friends. Conversely, they do not need other people to appropriate and remix their messages; they just need us to do what we are told. To go back to the examples above, it would seem inappropriate and disingenuous to piggyback on our informants' successes with our own self-aggrandizing thoughts: "Nice photos. See our recent article on deindustrialization in Baltimore for more context.” Shouldn't we just pass these social media along without subjecting them to our own hermeneutic violence? In other words, the Internet needs mindless carriers (although we would argue that these are simultaneously "mindful” of communities).

It is safe to say that this is not how most anthropologists would like to be described—as slacktivists or even as somnambulist zombies mindlessly passing media along. We are, after all, the ones who are supposed to be doing the interpreting. Our informants may produce anthropologically intended media, they may interview each other, and they may post insightful commentary; but these are data that wait for us to collect, collate, analyze, interpret, and publish. Even if we do so for all of the right public anthropology reasons, we very much mean to have the last word. This will-to-subjectivity is readily evident in the texts and media we create. In many ways, this will-to-subjectivity undergirded the popularity of the fascination with indigenous media in visual anthropology in the late 20th century (Ginsburg 1991). Critical of Rational Choice Theory and Western, 19th century models of subjectivity, anthropologists rest on their authority to create, to measure, to ratiocinate. Moreover, the qualities of the somnabulist in its passivity, submission and thoughtlessness are also associated with the terrifying domination of the person under advanced capitalism. We live in a world where increasing numbers of people have had their own wills ripped away from them as they are forced into prisons, migrant camps, and homelessness.

Obviously, this can (and certainly is) manipulated by corporations and governments, but the relationship need not only be one-sided. Our own social media lives suggest a more egalitarian relationship. Our friends post something - we duly send it along. We post something, and we expect that they will do the same. We are all full of pithy, political insights, hilarious jokes, photoshopping skills: we deserve to be copied, shared, reposted. In the age of social media, to be friends means to be ready to take the role of the passive carrier. For anthropologists, this means that sometimes we may be the imitated, and sometimes the imitator. After all, our informants may not always need our sagacity, but they will always need our support. That support will take many forms, some more active and agential than others. But following our informants is an important role, indispensable to a networked world.

\section{Conclusion: Tweeting and Retweeting for Anthropologists}

The question for a networked anthropology of Baltimore and the Baltimore Uprising is precisely one of 
authority. Do we need to author another "master" representation of a city in a representational field where hegemonic discourse abounds? Or, might we find a role not in producing ethnographic media, but in helping our interlocutors connect their media representations to various communities, including other activists, other change agents at local and national levels, and to other groups (including our students) who might become another source of propagation for both media and message? At our university, many students (and a few professors) are questioning what it means to be an "ally" to social activism. Does one speak for, speak with or speak alongside (Ruby 1991) our collaborators as they attempt to bring attention to issues in the city of Baltimore and advocate for social justice. Perhaps it is the job of the anthropologist in this instance not to do any speaking at all as we have argued in this paper and stand aside and act as conduits and carriers of an important message without any filtering or editing.

While the argument for keeping or letting go of ethnography (Ingold 2014) continues to be deliberated in open access journals such as Cultural Anthropology (Marcus 2016), we would like to argue for the ethnographic merit of ground-up media being produced by Baltimore citizens and organizations like Wide Angle Youth Media. This is not to usurp the role of the anthropologist, as we always have the important positionality of providing context, and it is not to align the media we are discussing with indigenous media that captured the fascination of the visual anthropology community in the late 20th century (Ginsburg, AbuLughod, and Larkin 2002; Turner 1992). For those that may be concerned with traditional academic outputs, perhaps this refashioning of our role provides a pivot point for a new form of collaborative based outcomes. The point of conversations over whether indigenous media could be considered ethnographic film was essentially an argument over who would have the last word on what that media would be called and whether or not indigenous media makers were producing data for us and creating media worlds that we would analyze. Our point is to help our community connect to media, to pass it along in the conduits of a networked anthropology that involves making media but also helping our collaborators network their media. Rather than serving the all too repeated role of the university and academics swooping in as elite outsiders there to ignore or co-opt community voices (Gomez 2015), we want to help imagine a different course. We would suggest using the links and videos in this article next time you teach about Baltimore rather than another clip from The Wire and become a carrier of this alternative media through your social media practices.

Countless blogs and posts advise people on best practices in tweets and re-tweeting. For the most part, they do so with an eye toward profit, brand management, and general self-aggrandizement. But with networked anthropology, the goal is different. How do we best tweet and re-tweet the media of the communities with which we work? How do we help people connect with others who will be beneficial to them? In other words, what does it mean to be an effective "ally" to these media producers? The danger, as many activists have critiqued, comes with the ways in which social media devolve into self-promotion, even when posters have putatively altruistic motives. By engaging in what Afro-Latinx trans-feminist blogger, Princess Harmony Rodriguez (2015) calls “ally theater," 14 where supposed allies of oppressed communities are performing their ally-ship only for self-aggrandizement — to gain more followers, to be recognized as "virtuous," and so on. Here, the goal should be to pass along media content to one's followers without calling attention to oneself.

Below, we have some suggestions for tweeting according to the practices we have worked out for networked 
anthropology. Of course, each social media platform works differently, and it is important to formulate your own practices for whatever platform you are using.

1. Have an interesting, diverse network. It is not enough to include friends and anthropologists in your circle of social media contacts. Not only should you be connected (however tangentially) to people in government and nonprofits, but you should make an effort to connect with people and institutions that are doing structurally similar work outside of your site.

2. Contribute regularly to social media and take the time to learn trending hashtags that might be relevant to different communities.

3. When you tweet media, you are there to promote someone else's work. Make sure you acknowledge the media creator, using the account name (e.g., “@wideangleym”) or, if they are not on Twitter, a link to their account on another social media. Add a brief description tailored to your followers, but avoid interpretation. The goal is to get people to share that media not to demonstrate your own acumen.

4. Add hashtags that will connect the media with appropriate contexts and will allow it to be found by people interested in these issues.

5. Most importantly, for the purposes of this article, we must insist: when you re-tweet, do not change their message.

Just push it along!

\section{Notes}

1 See Ta-Nehisi Coates' article, The Black Family in the Age of Mass Incarceration. The Atlantic, October 2015. Accessed April 1, 2017 at http://www.theatlantic.com/magazine/archive/2015/10/th e-black-family-in-the-ageof-mass-incarceration/403246/.

2 “The Corner” (2000), Home Box Office, created by David Simon and Ed Burns. "Homicide” (1993-1999), National Broadcasting Corporation, created by Paul Attanasio, and "The Wire” (2002-2008), Home Box Office, created by David Simon.

3 See the April 21, 2015 article,’Freddie Gray Arrest Timeline” by Adam Marton and Emma Patti Harris. 2015. Accessed April 1, 2017 at http://www.baltimoresun.com/news/maryland/baltimore-ci ty/bal-map-freddie-gray-arrest-timeline-20150421-htmlstory.html

4 See the Baltimore Neighborhood Indicators Alliance, "Vital Signs 14” (2016). Accessed May 10, 2016 at http://bniajfi.org/vital_signs/fullreport/

5 Quoted in the March 24, 2010 newspaper article on why people teach The Wire by Drake Bennett. Accessed April 1, 2017. http://www.slate.com/articles/arts/culturebox/2010/03/this_will_be_on_th e_midterm_you_feel_

6 Quoted in Bennett (2010) newspaper article. Accessed April 1, 2017 at http://www.slate.com/articl es/arts/culturebox/2010/03/this_will_be_on_the_midterm_you_feel_ 
7 In Isaac Chotiner, 2015's article, “Everything Is Not The Wire.” August 12, 2015. Accessed April 1, 2017 at http://www.slate.com/articles/arts/culturebox2015/08david_simon_interview_the_wire_ creator_on_his_new_series_freddie_gray_ta.html.

8 See Dave Zirin's 2015 article, “The Game Done Changed’: Reconsidering 'The Wire’ Amidst the Baltimore Uprising”, May 4, 2015. Accessed April 1, 2017: https:/www.thenation.com/article/ga me-done-changed-reconsidering-wire-amidst-baltimore-uprising/

$9 \quad$ The April 27, 2015, Baltimore Sun article by Justin Fenton and Erica Green, "Baltimore Rioting Kicked Off with Rumors of Purge” details this. Accessed April 1, 2017 at http://www.baltimoresu n.com/news/maryland/freddie-gray/bs-md-ci-freddie-gray-violence-chronology-20150427-story.ht $\mathrm{ml}$

10 See the Baltimore Sun article from April 28, 2015 by Kevin Rector, Scott Dance, and Luke Broadwater, “Riots Erupt: Baltimore Descends Into Chaos, Violence, Looting.” Accessed April 1, 2017 at http://www.baltimoresun.com/news/maryland/freddie-gray/bs-md-ci-police-student-violen ce-20150427-story.html

11 The 2013 Pew Research Center report by Aaron Smith, “African Americans and Technology Use.” Accessed April 1, 2017 at http://www.pewinternet.org/2014/01/06/african-americans-and-technolo gy-use/

12 See Eszter Hargittai's (2002) “Second-Level Digital Divide.” Accessed April 1, 2017. http://firstm onday.org/article/view/942/864

13 See "This Baltimore 20-Year-Old Just Won a Huge International Award for Taking Out a Giant Trash Incinerator” by Darryl Fears from April 18, 2016. Accessed at: https://www.washingtonpost. com/news/energy-environment/wp/2016/04/18/this-baltimore-20-year-old-just-won-a-huge-interna tional-award-for-taking-out-a-giant-trash-incinerator/?utm_term=.694dcda6cf6d

14 See Rodriguez's “Caitlyn Jenner, Social Media and Violent 'Solidarity”” article from June 8, 2015. Accessed April 1, 2017 at, https://www.bgdblog.org/2015/06/caitlyn-jenner-social-media-and-viol ent-solidarity-calling-out-abusive-material-sharing-it/ 